p-ISSN : 2655-7304

e-ISSN : 6655-8953

\title{
PERAN PEMERINTAH DESA DALAM MENGATASI KONFLIK PERKELAHIAN WARGA AKIBAT MINUMAN KERAS DI DESA AIBURA
}

\author{
${ }^{1}$ Danar Aswim, ${ }^{2}$ Petrus Kpalet, ${ }^{3}$ Theresia Afilanti, \\ 1,2,3 Institut Keguruan Dan Ilmu Pendidikan Muhammadiyah Maumere \\ Jl. Jendral Sudirman, Waioti, Maumere Nusa Tenggara Timur \\ 1danaraswim@gmail.com \\ 2petruskpalet@gmail.com \\ 3theresiaafilanti73@gmail.com
}

\begin{abstract}
This study aims to determine the role of the village government in overcoming the conflict of residents' fights due to alcohol and to determine the effectiveness of the role of the village government in overcoming the conflict of people's fights due to alcohol in Aibura Village, Waigete District, Sikka Regency. The research subjects were the Village Service Officer, the BPD secretary and traditional leaders. Researchers used a qualitative approach. Data collection techniques used are observation, interview, and documentation techniques. The data analysis technique used in this research is data collection, data reduction, and conclusion drawing. The results showed that the role of the Village Government in overcoming the conflict of residents'fights due to alcohol was the government by using a mediation pattern and ending with guni gelo customary law, which means that the payment from the perpetrator to the victim as a conflict resolution process as stated in the Call for Settlement of Customary Law and Minutes, while the effectiveness of the Village Government in overcoming the conflict of residents fighting due to alcohol. The settlement was carried out effectively by the Aibura Village Government by providing adequate infrastructure facilities, including the Head of the BPD, traditional leaders, village peace judges, hamlet heads, RT/RT heads. RW, Linmas members, perpetrators, victims, meeting place or location. From the results of the study, the authors conclude that the role of the government is expected to be maximized in providing socialization about liquor and providing counseling to the public about health, psychology so that people know the impact of consuming liquor and it is also hoped that the Aibura Village Government will make Village Regulations regarding liquor.
\end{abstract}

Keywords: Role, conflict, liquor

\begin{abstract}
Abstrak
Penelitian bertujuan untuk mengetahui Peran Pemerintah Desa dalam Mengatasi Konflik Perkelahian Warga akibat Minuman keras dan untuk mengetahui efektivitas Peran Pemerintah Desa dalam Mengatasi Konflik Perkelahian Warga akibat Minuman keras di Desa Aibura, Kecamatan Waigete, Kabupaten Sikka. Subyek penelitian Kaur Pelayaan Desa, sekertaris BPD dan tokoh adat. Peneliti menggunakan pendekatan kualitatif. Teknik pengumpulan data yang digunakan adalah teknik observasi, wawancara, dokumentasi. Teknik analisis data yang dilakukan dalam penelitian ini adalah pengumpulan data, reduksi data, penarikan kesimpulan. Hasil penelitian menunjukan bahwa peran Pemerintah Desa dalam mengatasi konflik perkelahian warga akibat minuman keras yaitu pemerintah dengan menggunakan pola mediasi dan diakhiri dengan hukum adat guni gelo yang artinya bayaran dari pihak pelaku terhadap pihak korban sebagai proses penyelesaian konflik seperti yang tertera dalam Panggilan Penyelesaian Hukum adat dan Berita Acara, sedangkan efektivitas Pemerintah Desa dalam mengatasi konflik perkelahian warga akibat minuman keras Penyelesaian tersebut dilakukan secara efektif oleh Pemerintah Desa Aibura dengan menyediakan sarana prasarana yang cukup memadai antara lain Ketua BPD, tokoh adat, hakim perdamaian desa, kepala dusun, para ketua RT/RW, anggota Linmas, pihak pelaku, pihak korban, tempat atau lokasi pertemuan. Dari hasil penelitian maka penulis mengambil kesimpulan bahwa peran pemerintah diharapkan lebih maksimal dalam memberikan sosialisasi tentang minuman keras dan memberikan penyuluhan kepada masyarakat mengenai kesehatan, psikologi agar masyarakat mengetahui dampak dari mengkonsumsi minuman keras dan diharapkan juga agar Pemerintah Desa Aibura membuat Peraturan Desa tentang minuman keras.
\end{abstract}

Kata Kunci: Peran, konflik, minuman keras. 
p-ISSN : 2655-7304

e-ISSN : 6655-8953

\section{PENDAHULUAN}

Bagi masyarakat di pedesaan, kebiasaan mengkonsumsi alkohol di pandang sebagai adat istiadat di daerah. Pandangan tersebut berimplikasi pada upaya untuk mempertahankan perilaku yang sesungguhnya membahayakan kesehatan sebagai sebuah kebiasaan masyarakat. Minuman keras sering dikonsumsi baik pada kegiatan adat, upacara keagamaan maupun sehari-hari. Kebiasaan mengkonsumsi minuman beralkohol bagi masyarakat perkotaan dipandang sebagai gaya hidup. Bagi masyarakat yang tinggal atau bekerja di sektor pariwisata minuman keras tentu sangat mudah ditemui. Budaya mengkonsumsi minuman keras ternyata tidak hanya di Indonesia saja tapi hampir di seluruh belahan dunia.[1]

Perkelahian adalah perihal berkelahi atau pertengkaran yang dilakukan dua orang atau lebih dengan kata-kata ataupun adu tenaga yang mengakibatkan salah satu atau yang terlibat mengalami luka. [2] dan Perkelahian juga merupakan bentuk dari salah satu tindakan kriminal yang sering terjadi dan menganggu ketertiban umum.

Seperti halnya dalam peraturan Undang-Undang kebijakan kriminalisasi terhadap Subjek Hukum yang mengkonsumsi minuman keras dapat merugikan orang lain atau umum, yakni sebagaimana ditentukan dalam Pasal 492 ayat (1) KUHP, pengguna minuman keras yang mengganggu ketertiban umum diancam kurungan penjara paling lama enam hari sedangkan pidana denda paling banyak tiga ratus tujuh puluh lima rupiah.[3] Sedangkan di Provinsi Nusa Tenggara Timur Gubernur telah melegalkan bahan baku alkohol dalam Peraturan Gubernur Nomor 44 tahun 2019 tentang Pemurnian dan Tata Kelola Minuman Tradisional beralkohol khas Nusa Tenggara Timur dalam Pasal 15 mengatakan mengatur larangan penyulingan minuman beralkohol tanpa ijin, larangan memproduksi minuman beralkohol dengan kadar ethanol diatas 55\%, penjual dilarang mengiklankan kepada masyarakat kecuali yang memiliki lebel dan tanda edar atau yang telah dimurnikan dan telah dilakukan standarisasi nasional.

Dalam pelaksanaan Peran Pemerintah Desa Aibura, seperti halnya tercantum dalam Undang - Undang No. 06 tahun 2014 Tentang Desa dalam Pasal 24 menyangkut asas Penyelenggaraan Pemerintahan Desa yang terdiri dari kepastian hukum, tertib Penyelenggaraan Pemerintahan, tertib kepentingan umum, keterbukaan proporsionalitas, profesionalitas, akuntabilitas, efektivitas, efesiensi, kearifan lokal, keberagaman, dan partisipasif [4] maka dengan demikian Pemerintah Desa Aibura perlu membuat konsep dasar hukum atau yang lebih dikenal dengan Peraturan Desa (Perdes) yang mengatur tentang minuman keras agar warga masyarakat membatasi diri untuk mengkonsumsi minuman keras tersebut. Dalam penegakan Peraturan Desanya Pemerintah Desa perlu bekerjasama dengan pihak keamanan Desa Aibura apakah itu Hansip untuk menjaga keamanan dan meredam kekacauan di Desa yang diakibatkan perkelahian warga sebagai akibat pengaruh minuman keras agar kehidupan damai dan harmonis dapat dirasakan oleh seluruh warga masyarakat.

\section{II.KAJIAN PUSTAKA}

Kepala desa bertugas menyelenggarakan pemerintahan desa, melaksanakaan pembangunan desa, pembinaan kemasyarakatan desa, dan pemberdayaan masyarakat desa. Wewenang Kepala Desa adalah memimpin penyelenggaraan Pemerintahan Desa, mengangkat dan memberhentikan perangkat desa, memegang kekuasaan pengelolaan Keuangan dan Aset Desa, menetapkan Peraturan Desa, menetapkan Anggaran Pendapatan dan Belanja Desa, membina ketenteraman dan ketertiban masyarakat desa, membina dan meningkatkan perekonomian desa serta mengintegrasikannya perekonomian skala produktif untuk sebesar - besarnya kemakmuran masyarakat desa. [5]

Menurut Webster istilah conflict dalam bahasa latinya berarti suatu perkelahian, peperangan, atau perjuangan, yaitu beberapa konfrontasi fisik antara beberapa pihak. [6] 
Minuman keras adalah minuman yang mengandung ethanol, Ethanol adalah bahan psikoaktif dan konsumsinya menyebabkan penurunan kesadaran. Minuman keras menjadi bagian yang tak terpisahkan dari perjalanan panjang peradapan manusia.[7]

Menurut Soerjono Soekanto salah satu fungsi hukum, baik sebagai sikap atau perilaku adalah membimbing perilaku manusia. Masalah pengaruh hukum tidak hanya terbatas pada timbulnya ketaatan atau kepatuhan pada hukum, tetapi mencakup efek total dari hukum terhadap sikap tindak atau perilaku baik yang bersifat positif maupun negatif. Efektivitas penegakan hukum sangat berkaiatan erat dengan efektivitas hukum maka hukum itu efektif diperlukan aparat penegak hukum untuk menegakkan sanksi tersebut. suatu sanksi dapat diaktualisasikan kepada masyarakat dalam bentuk ketaatan (compliance), dengan kondisi tersebut menunjukkan adanya indikator bahwa hukum tersebut adalah efektif. [8]

\section{METODE PENELITIAN}

Metode Penelitian yang digunakan menggunakan pendekatan deskriptif kualitatif. Menurut Lexy J. Moleong pendekatan deskriptif kualitatif, yaitu prosedur penelitian yang menghasilkan data deskriptif berupa kata-kata tertulis atau lisan dari orang-orang dan perilaku yang diamati.[9] Sumber data yang digunakan peneliti dalam penelitian ini adalah data primer dan data sekunder. Sugiyono mendefinisikan sumber data primer dan data sekunder adalah sumber data primer yaitu sumber data yang langsung memberikan data kepada pengumpul data.[10] Adapun sumber data primer dalam penelitian ini adalah wawancara dengan Kaur Pelayanan Desa, Sekertaris BPD dan tokoh Adat. Sedangkan sumber data sekunder adalah sumber data yang tidak langsung memberikan data, dari sumber lain seperti Buku, Undang-Undang dan Artikel. Teknik pengumpulan data melalui pengamatan, wawancara, dokumentasi yang secara langsung yang di lakukan di lapangan atau di tempat penelitian dengan titik fokus peran Pemerintah Desa dalam mengatasi konflik perkelahian warga akibat minuman keras di Desa Aibura Kecamatan Waigete Kabupaten Sikka.

\section{HASIL DAN PEMBAHASAN}

1. Peran Pemerintah Desa Aibura Dalam Mengatasi Konflik Perkelahian Warga Akibat Minuman Keras.

Peran berarti sesuatu yang dimainkan atau dijalankan, dalam undang-undang No. 06 Tahun 2014 tentang Desa dalam Pasal 24 menyangkut asas penyelenggaraan Pemerintah Desa yang terdiri dari kepastian hukum, tertib Penyelenggaraan Pemerintahan, tertib kepentingan umum, dan efektivitas. Dalam pelaksanaan Pemerintah Desa menetapakan peraturan yang digunakan untuk memantau segala aktivitas masyarakat akan tetapi peraturan yang dibuat tidak menentang kepentingan umum atau peraturan yang lebih tinggi.

Konflik sudah menjadi bagian dari kehidupan manusia. Konflik kerap kali hadir di kehidupan sehari-hari kita, antara perorangan, anggota kelurga maupun antara warga masyarakat. Konflik sebagai bentuk interaksi sosial munculnya konflik biasanya karena perbedaan antara individu maupun kelompok. Baik itu perbedaan pendapat, penampilan, ras, ideologi, budaya dan perbedaan lain, hal senada juga di kemukakan oleh Seorjono Sukanto menyebutkan bahwa konflik merupakan suatu proses sosial individual atau kelompok yang berusaha memenuhi tujuanya dengan jalan menentang pihak lawan yang disertai dengan ancaman atau kekerasan.[11]

Konflik perkelahian warga akibat minuman keras yang terjadi di Desa Aibura karena adanya beberapa faktor berdasarkan hasil wawancara dengan Kaur Pelayaanan Desa sebagai berikut: 
1. Kelebihan Mengkonsumsi Minuman Keras (Beralkohol)

Seseorang meneguk minuman dalam jumlah banyak berturut-turut dalam waktu singkat bertujuan untuk mabuk. Mabuk minuman keras dapat memperburuk kerjanya akal sehat dan kontrol diri.

2. Setelah mengkonsumsi minuman keras seseorang mudah tersinggung dalam berkomunikasi antara sesama sehingga dapat menimbulkan perkelahian.

Pemerintah Desa tidak hanya bertugas menyelenggarakan pemerintahan desa, melaksanakaan pembangunan desa, tetapi Pemerintah Desa memiliki tugas, kewajiaban dan wewenang dalam penyelesaian konflik perkelahian akibat minuman keras yang melibatkan mayarakat, proses penyelesaian bertempat di kantor Desa Aibura. Berdasarkan hasil wawancara dengan Kaur Pelayanan Desa menjelaskan dalam proses penyelesaian dimana kedua belah pihak bersengketa bersama-sama bersepakat untuk menunjuk pihak ketiga yaitu Pemerintah Desa yang akan memberikan keputusan yang mendukung untuk proses penyelesaian konflik.

Meskipun Peraturan Desa secara tertulis belum dibuat oleh Pemerintah Desa Aibura, akan tetapi dalam proses menyelesaiakan konflik Pemerintah Desa bersama Lembaga Adat menggunakan Hukum Adat atau hukum tidak tertulis sebagai dasar untuk memberikan sanksi sosial kepada masyarakat atau warga yang melakukan tindakan yang dapat merugikan orang lain.

2. Efektivitas Peran Pemerintah Desa Dalam Mengatasi Konflik Perkelahian Warga Akibat Minuman Keras.

Efektivitas bahwa tujuan yang telah direncanakan sebelumnya dapat tercapai atau dengan kata sasaran tercapai karena adanya proses kegiatan.[12] Pengertian tersebut sesuai dengan pendapat Barda Nawawi Arief efektivitas mengandung arti keefektifan pengaruh atau efek keberhasilan.[13]

Pemerintah Desa dalam penyelesaian konflik perkelahian akibat minuman keras, dimana pemerintah desa harus memprioritaskan hubungan baik dan perlu adanya kerja sama yang baik dari semua pihak yang terlibat untuk mencapai keefektivan sebuah konflik. Penilaian efektivitas menurut Ali Muhidin menjelaskan berbagai pendekatan salah satunya pendekatan yang berfokus pada tujuan dan keputusan. Pendekatan ini memakai tujuan program sebagai kriteria untuk menentukan keberhasilan serta menekankan pada peranan informasi yang sistematik. [14]

Berdasarkan observasi dan hasil wawancara terhadap beberapa informan mengatakan bahwa proses penyelesaian konflik minuman keras di Desa Aibura dinilai efektif. Hal ini dapat dilihat dari proses penyelsaian konflik yang dilakukan oleh Pemerintah Desa, Pemerintah Desa mengeluarkan surat Panggilan Penyelesaian Hukum Adat dan proses penyelesaian yang tertera dalam Berita Acara, Nomor D.A. 141/01/BA/1V/2020 dalam Pelaksanaan pemerintah desa menyediakan sarana dan prasarana yang cukup memadai antara lain Ketua BPD, tokoh adat, hakim perdamaian desa, kepala dusun, para ketua RT/RW, anggota Linmas, pihak pelaku, pihak korban, tempat atau lokasi pertemuan. Penindaklanjutan konflik tersebut diakhiri dengan hukum adat dalam bahasa daerah disebut Guni Gelo artinya Pihak pelaku harus membayar denda kepada pihak yang menjadi korban konflik berupa uang, hewan berupa kuda dan beras sebagai denda adat dalam penyelesaian konflik. Hukum adat tersebut digunakan sebagai patokan atau ukuran dalam budaya setempat. Serta hasil keputusan sanksi tersebut dapat diterima oleh kedua belah pihak yang berkonflik. 
Tabel 1.1 Wawancara

\begin{tabular}{|c|c|c|}
\hline No & Aspek yang di wawancarai & Subyek 1 \\
\hline 1 & $\begin{array}{l}\text { Bagaimana Peran Pemerintah Desa } \\
\text { dalam mengatasi konflik } \\
\text { perkelahian warga sebagai akibat } \\
\text { pengaruh minuman keras? }\end{array}$ & $\begin{array}{l}\text { Mengatakan bahwa dalam menjalankan } \\
\text { peran atau penyelesaian sebuah masalah } \\
\text { atau konflik tentunya harus berpegang } \\
\text { pada sebuah aturan atau pedoman atau } \\
\text { lebih dikenal dengan perdes akan tetapi } \\
\text { perdes yang mengatur minuman keras } \\
\text { belum di bentuk oleh lembaga Badan } \\
\text { Permusyawaratan Desa sekarang di desa } \\
\text { masih menggunakan atau menerapkan } \\
\text { hukum adat yang merupakan adat istiadat } \\
\text { budaya setempat. }\end{array}$ \\
\hline 2 & Aspek yang di wawancarai & Subyek 2 \\
\hline & $\begin{array}{l}\text { Bagaimana efektivitas peran } \\
\text { pemerintah desa dalam mengatasi } \\
\text { konflik perkelahian warga akibat } \\
\text { minuman keras? }\end{array}$ & $\begin{array}{l}\text { Mengatakan bahwa konflik dialami oleh } \\
\text { warga dapat diselesaiakan secara efektif } \\
\text { oleh Pemerintah Desa Aibura dan Tokoh } \\
\text { Adat dalam penyelesaian konflik tersebut } \\
\text { Pemerintah Desa Aibura menggunakkan } \\
\text { pola mediasi dan diakhiri dengan Hukum } \\
\text { adat guni gelo berupa uang. dan desa } \\
\text { selalu aktif dalam memberikan saran-saran } \\
\text { yang baik kepada pihak yang berkonflik } \\
\text { agar ke depanya tidak lagi melakukan } \\
\text { konflik yang sama dan saling menghargai, } \\
\text { selalu ada rasa persaudaraan yang di } \\
\text { tanamkan dalam hidup setiap hari. }\end{array}$ \\
\hline
\end{tabular}

Keterangan : Tabel diatas merupakan pedoman wawancara peneliti untuk menemukan data di lapangan dari hasil wawancara dengan informan.

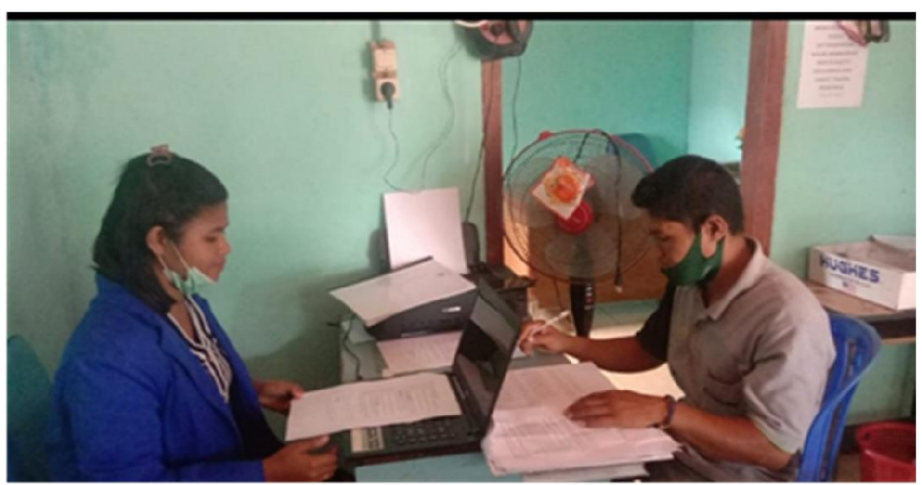

Sumber : Kamera pengambilan data 2021 
p-ISSN : 2655-7304

e-ISSN : 6655-8953

\section{KESIMPULAN DAN SARAN}

Perkelahian akibat minuman keras terjadi karena orang atau warga tersebut mengkonsumsi minuman keras dalam jumlah berlebihan dalam waktu singkat yang menyebabkan seseorang dapat mabuk. Sehingga berdampak negatif pada sesama warga lainnya dan lingkungan sosial. Perkelahian warga akibat minuman keras yang terjadi dapat diselesaiakan secara efektif oleh Pemerintah Desa Aibura dengan menggunakan hukum adat guni gelo artinya pihak pelaku harus membayar denda kepada pihak yang menjadi korban konflik berupa uang, hewan berupa kuda dan beras sebagai denda adat dalam penyelesaian konflik, karena belum ada peraturan yang mengatur tentang minuman keras. Berdasarkan kesimpulan tersebut maka saran-saran yang disampaikan pada artikel ini sebagai berikut : Bagi Pemerintah Desa diharapkan lebih memaksimalkan dalam memberikan sosialisasi tentang minuman keras dan memberikan penyuluhan kepada masyarakat mengenai kesehatan, psikologi agar masyarakat mengetahui dampak dari mengkonsumsi minuman keras dan diharapkan juga agar Pemerintah Desa Aibura membuat satu Peraturan Desa tentang minuman keras. Sedangkan bagi masyarakat diharapakan agar masyarakat dapat mengontrol atau membatasi diri dalam mengkonsumsi minuman keras secara berlebihan agar tidak terjadi tindakan kriminal yang bisa meresahkan masyarakat.

\section{DAFTAR PUSTAKA}

[1] Dewi Bunga. (2015). Urgensi RUU Minuman Beralkohol dalam Pembaharuan Hukum di Indonesia. Jurnal Hukum Undiknas, Vol 2, No. 2.

[2] Muh. Taufik Silayar. (2013). Tinjauan Kriminiologis terhadap Perkelahian Antara Warga di Kabupaten Kepulauan Sula, Provinsi Maluku Utara Universitas Hassanudin Makassar.

[3] Kitab Undang-Undang Hukum Pidana

[4] Undang-Undang Nomor 06 Tahun 2014 Tentang Desa

[5] Kushandajani. (2016). Implikasi UU No.06 Tentang Desa Terhadap Penyelenggaraan Pemerintahan Desa. Jurnal Ilmiah Ilmu Pemerintahan, Vol 2, No. 1.

[6] Pruit, Rubin. (2009). Teori Konflik Sosial (cetakan 11). Yogyakarta: Pustaka Pelajar.

[7] Darmawan. (2010). Pengertian Minuman Keras dan Dampaknya. Bandung: Remaja Rosdakarya.

[8] Soerjono Soekanto. (2007). Sosiologi Suatu Pengantar. Jakarta: Raja Grapindo Persada.

[9] Lexy J. Moleong. (2006). Metodologi penelitian kualitatif. Bandung: PT. Remaja Rosdakarya.

[10] Sugiyono, (2015). Metode Penelitian Kombinasi (Mix Methods). Bandung: Alfaberta.

[11] Ahmadi. A. (2009). Psikologi sosial. Jakarta: Rineka cipta.

[12] Muhammad Ali. (1997). Penelitian Pendidikan Prosedur dan Strategi. Bandung: Angkasa.

[13] Barda Nawawi Arief. (2003). Kapita Selekta Hukum Pidana. Bandung: Citra Aditya Bakti.

[14] Ali Muhidin Sambas. (2009). Konsep Efektivitas Pembelajaran, Bandung: Pustaka Setia. 